\title{
Saffron, an alternative crop for sustainable agricultural systems. A review
}

\author{
F. GRESTA ${ }^{1 *}$, G.M. LOMBARdo ${ }^{1}$, L. SIRACUSA ${ }^{2}$, G. RUBERTO ${ }^{2}$ \\ ${ }^{1}$ Dipartimento di Scienze Agronomiche, Agrochimiche e delle Produzioni Animali, Università di Catania, Via Valdisavoia 5, 95123 Catania, Italy \\ ${ }^{2}$ Istituto del CNR di Chimica Biomolecolare, Via del Santuario 110, 95028 Valverde CT, Italy
}

(Accepted 31 May 2007)

\begin{abstract}
Saffron (Crocus sativus L.) is an autumnal flowering geophite whose dried stigmas, well known for their aromatic and colouring power, have been used since immemorial time as a spice in human nutrition, for medicinal purposes and as a dye. Many doubts remain on its origin; it was probably selected and domesticated in Crete during the Late Bronze Age. Saffron is an autotriploid geophyte species, self- and out-sterile and mostly male-sterile and therefore unable to produce seed, that reproduces by means of corms. Furthermore, it has a reverse biological cycle compared with the majority of cultivated and spontaneous plants: flowering first in October-November, then vegetative development until May, which means that the vegetative development is not directly important for production of stigmas, but for the production of new corms. Due to its unique biological, physiological and agronomic traits, saffron is able to exploit marginal land and to be included in low-input cropping systems, representing an alternative viable crop for sustainable agriculture. Notwithstanding this great potential and the considerable increase in new generation consumer demand for saffron, the future of the plant is still uncertain. Indeed, the main obstacles to saffron production are: (1) the limited areas of cultivation in countries where it is traditionally grown, (2) the great amount of sophisticated spice, (3) management techniques executed by hand, and (4) the very high price of the spice. Here we review the main biological, genetic and ecological traits associated with agronomic management techniques of saffron in relation to environmental conditions. Colour, taste and aroma are the essential features on which the quality of saffron stigmas is founded. In turn, these aspects are strictly connected with the biomolecular composition of the stigmas, namely, the carotenoids and their derivatives. With this in mind, the biosynthetic pathway that leads to the formation of saffron secondary metabolites and their abundance in the spice is presented, together with the biomedical properties commonly associated with saffron. Furthermore, a detailed overview of the more recent instrumental methods to assess the quality of saffron, strictly from a chemical point of view, will be discussed.
\end{abstract}

Crocus sativus / saffron / carotenoids / yields / quality / sustainability

\section{INTRODUCTION}

Saffron (Crocus sativus L.) belongs to the large family of Iridacee and to the genus Crocus, which includes about 80 species distributed primarily in the Mediterranean and south-western Asia (Fig. 1). Among these, saffron, recognised as the most expensive spice in the world (Winterhalter and Straubinger, 2000; Fernandez, 2004), certainly represents the most interesting and attractive species, for the colouring, bitterness and aromatic power of its dried stigmas.

Saffron is a geophite herbaceous plant, whose stigmas have been used from ancient times as a spice in food, as a dye, in perfumes and cosmetics preparation and for medicinal purposes (Basker and Negbi, 1983). Nowadays, it is almost exclusively used for food colouring and flavouring, even though recent studies are boosting interest in its medical properties. Saffron is known only as a cultivated species; it propagates solely vegetatively by means of corms, underground stems acting as storage and reproduction structures, and does not produce seeds or exist as a spontaneous plant.

* Corresponding author: fgresta@unict.it

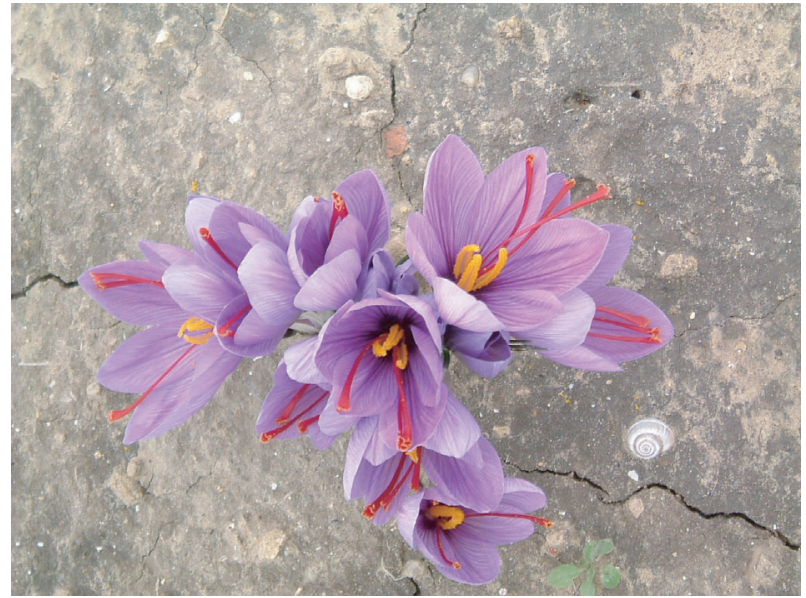

Figure 1. Saffron (Crocus sativus L.)

Saffron is cultivated in a wide range of environments with mild to dry climates. For a long time, saffron has been neglected by researchers and farmers since it was considered a minor crop used only for agricultural diversification. However, 
Table I. Estimate of saffron world production (modified from Negbi, 1999).

\begin{tabular}{lccl}
\hline Country & Area (ha) & Production $(\mathrm{kg})$ & \\
\hline Iran & 47000 & 160000 & Ehsanzadeh et al., 2004 \\
India & - & $8000-10000$ & Fernandez, 2004 \\
Greece & 860 & $4000-6000$ & Fernandez, 2004 \\
Azerbaijan & 675 & - & Azizbekova and Milyaeva, 1999 \\
Morocco & 500 & 1000 & Ait-Oubahou and El-Otmani, 1999 \\
Spain & 200 & $300-500$ & Fernandez, 2004 \\
Italy & 35 & 120 & (personal communications) \\
France & 1 & 4 & Girard and Navarrete, 2005 \\
Turkey & - & 10 & Thiercelin, 2004 \\
Switzerland & - & 0.4 & Negbi, 1999 \\
\hline
\end{tabular}

in the last few years it is gaining a more interesting role in low-input agricultural systems and as an alternative crop. Moreover, saffron is a very attractive crop for organic and low imput agriculture considering that no irrigation, chemical fertilisation or chemical weed treatments are applied in some environments in which it is cultivated. The main management techniques such as corm planting, flower harvest, stigma separation and corm lifting are carried out manually and this contributes to its high price. Commercial saffron is defined as "the stigmas of C. sativus L. dried, dark red in colour and trumpet shaped, serrated or indented at the distal end. The length is between $20 \mathrm{~mm}$ and $40 \mathrm{~mm}$. The stigmas may be isolated or joined in pairs or threes at the end of the portion of the style, which is white/yellow in colour" (ISO, 2003). Saffron's colour, bitter taste and aroma are its three main and particular characteristics, which are associated with three different molecular features: crocins, picrocrocins and safranal, respectively.

These and other characteristics make saffron one of the most interesting alternative rediscovered crops, especially for the Mediterranean environment, where the hot, dry summer climate inhibits the spread of pathogenic disease. The relaunching of saffron production requires research studies, improvement in knowledge and a synergic action between scientific and empiric information.

\section{ORIGIN AND DISTRIBUTION}

The word saffron probably comes from the Persian sahafaran, that derives from asfar, meaning yellow. Its centre of origin is not entirely certain. Some information is given on saffron origin and domestication: Vavilov indicates the Middle East (1951), while other authors suggest Asia Minor or the south-west Greek islands as its probable area of origin (Tammaro, 1990). Results from recent research (Negbi, 1999) show that Crocus sativus was probably selected and domesticated in Crete during the Late Bronze Age. From here, it spread to India, China and the Middle Eastern countries. From these latter, the Arabs brought saffron to all Mediterranean Europe (Ingram, 1969). Anyway, according to recent archaeological studies on ancient coins and inscriptions (Manganaro, 2001), saffron was already cultivated in the Greek-Roman period in Sicily.
Even if many legends surround the origin of saffron, the first detailed historic information dates back to Papyrus Ebers (1550 years B.C.) that documents the use of saffron for medical purposes and frescoes in the Minoic Palace of Knossos (about 1500 years B.C.), depicting young girls gathering crocus flowers in baskets. Many other historic references are reported in the Old Testament and in the texts of many Greek (such as Theophrastus, Aeschylus, Pindarus, Hesiod, Hippocrates and others) and Roman (such as Plinus, Largus and Celsus) writers, documenting its use for the preparation of perfume, food and as a dye.

Due to the small area of cultivation and the minor importance given to this crop, information on its diffusion throughout the world is uncertain. Total world saffron production is estimated at about 205 tons per year (Fernandez, 2004). In the last century, saffron cultivation areas changed completely: in European countries, despite an increase in the price of saffron, traditional cultivated areas (Spain, Italy and Greece) underwent a severe reduction. In Spain, saffron dropped from 6000 ha in 1971 to 200 ha today (Fernandez, 2004), in Greece from 1600 in 1982 to 860 according to the most recent information (Skubris, 1990; Fernandez, 2004) and in central Italy (Abruzzo) it fell from 300 ha in 1910 to 6 ha some years ago. On the contrary, an enormous increase has been registered in Iran in the last 30 years. The main reason for this change is certainly due to the high requirement of manual labour, concentrated into a few days and into a few hours a day, and to the increase in labour costs. Today, the main producer countries are Iran, India and Greece (Tab. 1). Iran has the widest area cultivated with saffron: Ehsanzadeh et al. (2004) report an area of 47000 ha, most of which is grown in the Khorasan province. In India, saffron is widely cultivated in Kashmir, while there are notably less areas, even if considerable given the typology of the crop, in Greece (Kozani, western Macedonia), Azerbaijan (Aspheron peninsula) and Morocco (Taliouine area). There are also small cultivation areas in Italy, about 35 ha, for the most part concentrated in Sardinia (about 25 ha in $\mathrm{S}$. Gavino, Cagliari province) and Abruzzo (about 6 ha in Altopiano di Navelli, L'Aquila), France, Turkey, Switzerland, Israel, Pakistan, China, Egypt, United Arab Emirates, Japan and Australia (Fernandez, 2004).

The major saffron-importing countries are Germany, Italy, the USA, Switzerland, the United Kingdom and France 
(International Trade Centre, 2006). Spain imports large quantities of saffron as well, especially from Iran, Greece and Morocco for re-export and for its internal market needs.

\section{GENETIC TRAITS}

Saffron is a triploid geophyte species $(\mathrm{x}=8 ; 2 \mathrm{n}=3 \mathrm{x}=24)$ (Mathew, 1977; Ghaffari, 1986), self- and out-sterile and mostly male-sterile (Grilli Caiola, 2005) and therefore unable to produce seed. Its sterility depends on an irregular triploid meiosis, resulting in many anomalies in sporogenesis and gametophyte development (Chichiriccò, 1999; Grilli Caiola, 2004) and then in a production of abnormal pollen. In fact, at maturity, about $70 \%$ of the ovules of $C$. sativus contain a normal Polygonum-type sac (Battaglia, 1963; Chichiriccò, 1984; Grilli Caiola and Chichiricco, 1991), while a very high incidence of low pollen viability and germination due to meiotic abnormalities was detected (Chichiriccò and Grilli Caiola, 1984; Grilli Caiola, 2004). For these reasons saffron presents self-sterile pollination. In the past, seeds in the field have been reported only once (Piccioli, 1932), while in vitro cross-pollination (fertilisation) of the ovary of $C$. sativus with pollen of C. cartwrightianus (Grilli Caiola, 1999, 2005) and C. tomasii Ten. (a self-incompatible, but cross-fertile species) (Chichiriccò, 1999) resulted in the production of capsules and viable seeds. C. hadriaticus is able to fertilise $C$. sativus as well (Grilli Caiola et al., 2001). On the contrary, pollination of other Crocus species with pollen of $C$. sativus did not result in production of any seeds (Grilli Caiola, 2005). Even if Angiosperms can also produce apomictic embryos, this was never detected in saffron (Chichiriccò, 1996; Grilli Caiola, 2005).

The genetic origin of $C$. sativus is not clear: it may have occurred by autotriploidy from a wild Crocus, probably by fertilisation of a diploid unreduced egg cell by a haploid sperm cell or a haploid egg cell by two haploid sperms (Chichiriccò, 1984; Grilli Caiola, 2004, 2005), or by allopolyploid through the hybridisation of $C$. cartwrightianus and $C$. hadriaticus (Castillo et al., 2005). Information on saffron ancestors is not univocal: Brighton (1977) in a kariological study suggested that possible ancestors of $C$. sativus are $C$. cartwrightianus or $C$. thomasii. Recent AFLP analysis (Amplified Fragment Length Polymorphisms) confirmed that the quantitative and qualitative traits of their DNA are compatible with $C$. sativus (Zubor et al., 2004). Between these, some authors indicate $C$. cartwrightianus as the most probable ancestor (Mathew, 1999; Brandizzi and Grilli Caiola, 1998; Grilli Caiola et al., 2004). Moreover, flowering in C. cartwrightianus has close similarities to $C$. sativus.

Brighton (1977) affirms that saffron exhibits fairly homogenous and stable biological traits all over the world and differs only in minor morphological and biochemical characteristics such as some morphometric features (Tammaro, 1990). This observation was in part confirmed by a recent investigation into the DNA of saffron from 5 different locations (Europe and Israel) with RAPD methodology (Random Amplified Polymorphic DNA) that did not identify any genomic differences (Grilli Caiola et al., 2004). However, the samples from differ-

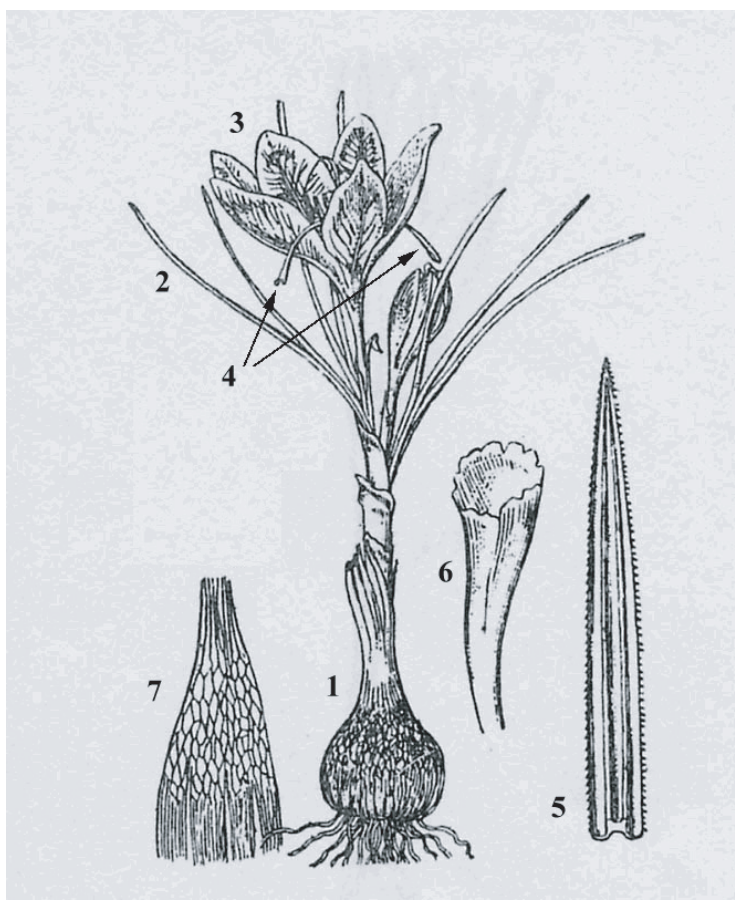

Figure 2. Main morphological characteristics of saffron. 1. Corm; 2. Leaves; 3. Tepals; 4. Stigmas; 5. Close-up of the leaf; 6. Close-up of the terminal trumpet-like part of the stigmas; 7 Reticulated tunic of the corm (modified from Pignatti, 1982).

ent countries showed clear morphological differences, so we may assume that the screening method used was unable to detect genetic differences.

\section{DESCRIPTION}

\subsection{Morphology}

Morphologically saffron, being a clone, has great uniformity over a wide cultivated area (Brighton, 1977; Mathew, 1977). The corms, a tuberous-bulb formation, are squashed, flattened at the base, to about $4.5-5.5 \mathrm{~cm}$ diameter, and covered by several reticulated fibrous tunics (Fig. 2). Corms have one or two main buds in the apex position and about (depending on the dimension) 4-5 or more secondary buds, arranged irregularly in spiral form. Corms derived from secondary buds are smaller than corms produced by apical buds. Each mother corm produces 1-3 medium-big daughter corms from apical buds and several small corms from lateral buds, depending on the size of the mother corm. Leaves (from 6 to 9) are erect, narrow, grass-like and dark green coloured. The flower, usually one or several, but even as many as 12 , is composed of a perianth of 6 violet tepals (perigon) connate at the base in a long and narrow tube. The pistil is composed of an inferior ovary from which a slender style, $9-10 \mathrm{~cm}$ long, arises. The style is divided into 3 dark red branches, each one up to $30-40 \mathrm{~mm}$ long, named stigmas, which droop over the perianth segments. Three stamens with two lobed anthers each are also present. 


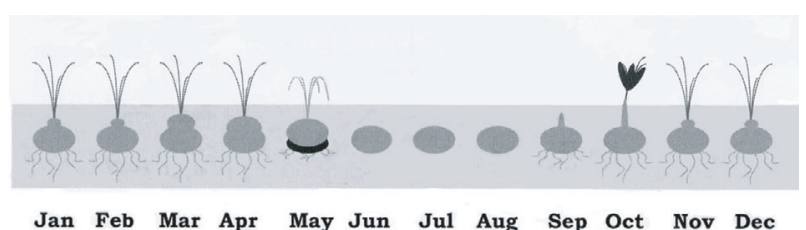

Figure 3. Biological cycle of saffron (from Alvarez-Orti et al., 2004).

Some variants of saffron with a higher number of stigmas have been reported by Estilai (1978), Dhar et al. (1988), Piccioli (1932) and Gresta et al. (unpublished). However, they do not reappear the following year and so should be considered somoclonal variations that do not pass on to the next generations (Grilli Caiola, personal communication). Saffron has two types of roots: fibrous, thin roots at the base of the mother corm, and contractile roots formed at the base of lateral buds (Kalesi et al., 2004), thicker than the former with a tuber organ aspect that give the corm the ability to maintain depth in the soil (Chio-Sang, 1996). C. sativus may be distinguished from other spontaneous Crocus species lacking in aromatic power and that are sometimes used in the sophistication of the spice, essentially for the greater dimension (gigantism) of vegetative (leaves, corms and floral axes) and flowering parts (stigmas, stamens and tepals).

\subsection{Biology and physiology}

Saffron is an autumnal flowering geophite characterised by a long summer rest in which the plant survives periods of drought by means of corms (Fig. 3). Its biological cycle starts with its above-ground vegetative growth at the first autumn rains with the emission of leaves and flowers almost immediately and ends with the production of replacement corms in about 220 days. Unlike many other species of the Crocus genus that flower in the winter-spring period, in saffron flowering can occur from mid-October to the end of November, essentially depending on the climatic conditions. It generally starts from 60 to 90 days after planting, mainly depending on sowing time, but snowy and cold periods may retard flowering. Flower induction is a very complicated mechanism in saffron. Little information is available on flower induction in saffron; nevertheless, flowering seems to be mainly influenced by environmental factor such as Molina et al. (2004a) ascribe the ability to influence the beginning and duration of flowering to temperature, while an inferior or negligible role is ascribed to soil water content. Certainly, as in most geophyte plants, both seasonal and daily thermoperiodism are involved as the main environmental factors inducing flowering (Halevy, 1990).

Saffron is considered a subhysteranthous plant (Mathew, 1977, 1982). Indeed, the phenological sequence of the different phases is not predetermined: flowers can appear before, at the same time or after leaf appearance. Hysteranthy is a strange phenomenon present in many geophytes such as Scilla autumnalis, Uriginea maritima Amaryllis belladonna, Pancratium sickenbergeri, Colchicum alpinum, Sternbergia colchiciflora,
Ornithogalum pyrenaicum, etc., that flower before leaf emergence, supporting flowers only with the storage nutrients concentrated in the corm (Dafni et al., 1981). In Mediterranean geophytes, this response can be explained as a strategic adaptation to the temporal unpredictability of the onset of rain after the summer drought (Debussche et al., 2004). Hysteranthy may be of great importance in saffron with respect to mechanisation of the flower harvest. Flower-cutting machines could be used to harvest flowers and avoid damaging the leaves. Hysteranthy can be induced by controlled temperature during corm storage: a dry storage of corms at $15{ }^{\circ} \mathrm{C}$ for 35 days resulted in flowering prior to leaf appearance (hysteranthy) and in a more synchronous flowering (Plessner et al., 1989). Flower and corm production was also improved by the $15^{\circ} \mathrm{C}$ pretreatment.

A short growth phase of the vegetative part is also detectable in early spring, in which the photosynthetic activity of leaves allows the formation of replacement corms. Afterwards, when the temperature rises, leaves wither, and the plant remains only below-ground by means of the corm. Root growth occurs from autumn to the spring period, in which the mother corm is completely empty and daughter corms are produced to propagate the plant. The average size of replacement corms is inversely related to their number (Negbi, 1990).

\section{ADAPTATION}

\subsection{Climate}

Saffron is cultivated in very different environmental conditions with good results: in Italy, saffron is cultivated in Navelli, from 650 to $1100 \mathrm{~m}$ above sea level (a.s.l.) with an average annual rainfall of about $700 \mathrm{~mm}$, and in Sardinia in S. Gavino Monreale, from 50 to $140 \mathrm{~m}$ a.s.l. with $300-600 \mathrm{~mm}$ rainfall. In Greece, cultivation areas are located in Kozani Macedonia, about 650-700 $\mathrm{m}$ above sea level, and precipitations are around $560 \mathrm{~mm}$ per year, while in Spain, La Mancha and Castille, it is cultivated under $250-500 \mathrm{~mm}$ rainfall, usually in irrigated conditions (Tammaro, 1990).

Average annual temperatures are around $11.3{ }^{\circ} \mathrm{C}$ in Navelli with $20-22{ }^{\circ} \mathrm{C}$ in summer and $2-3{ }^{\circ} \mathrm{C}$ in winter, when snow can cover the land for up to one month; in Sardinia $16-20^{\circ} \mathrm{C}$ with $25{ }^{\circ} \mathrm{C}$ in summer and $10{ }^{\circ} \mathrm{C}$ in winter; in Kozani $12.5{ }^{\circ} \mathrm{C}$ with $23{ }^{\circ} \mathrm{C}$ in summer and $2-5{ }^{\circ} \mathrm{C}$ in winter, and in La Mancha and Castille $16-20{ }^{\circ} \mathrm{C}$ with $25{ }^{\circ} \mathrm{C}$ in summer and $5-7{ }^{\circ} \mathrm{C}$ in winter. In India, saffron is cultivated in areas with a sub-tropical climate (Sampathu et al., 1984). Mollafilabi (2004) reports that saffron is able to tolerate substantial cold temperatures of $-18{ }^{\circ} \mathrm{C}$, and occasional winter snow, even if with reduced productivity. Significant snow damage in saffron was ascertained only during flowering because of flower freezing and decomposing (Tammaro, 1990), while minor problems were observed in leaves even with short-lasting snow (Ait-Oubahou and El-Otmani, 1999). Autumn temperatures in Azerbaijan saffron-cultivated areas fall to $-5.9{ }^{\circ} \mathrm{C}$ (Azizbekova and Milyaeva, 1999). During the summer rest period, maximum temperatures of $30-40{ }^{\circ} \mathrm{C}$ can be tolerated as well. 
Saffron prefers direct sun exposure, even though in India it is cultivated together with almond trees. According to Fernandez (2004) and Mollafilabi (2004), the best climatic conditions for high yields are rainfall in the autumn, warm summers and mild winters.

\subsection{Soil}

Saffron grows on a wide range of soils. Skrubis (1990) indicates that the best performances are achieved on well-drained clay-calcareous and deep soil. Fernandez (2004) suggests that clay is a good soil for saffron, while Sampathu et al. (1984) report that saffron requires a well-ploughed sandy-loamy soil or a well-drained clay soil. Saffron is also cultivated on sandy soil in Azerbaijan (Azizbekova and Milyaeva, 1999). Tammaro (1999) suggests that the humus-clay soil of Navelli guarantees good water storage for saffron. Saffron grows well in salty soil, while a limiting factor could be calcium carbonate deficiency (Mollafilabi, 2004). Good soil $\mathrm{pH}$ ranges from neutral to slightly alkaline. Conflicting information is reported on nutrient needs among different authors (Goliaris, 1999; Tammaro, 1999; Skrubis, 1990).

\section{MANAGEMENT TECHNIQUES}

\subsection{General}

Most crop management techniques, above all planting, weeding, flower picking and separating, are performed by hand all over the world (Bali and Sagwal, 1987; Ingram, 1969; Tammaro and Di Francesco, 1978). For this reason, saffron cultivation is painstaking and expensive. Saffron cultivation is generally carried out as a perennial cycle, but an annual crop system is adopted in Navelli, Italy. Perennial crop techniques have highly variable durations from place to place: from 3-4 years in Spain, 6-8 years in India and Greece and up to 12 in Morocco (Ait-Oubahou and El-Otmani, 1999). With the aging of the saffron field, generally after $4-5$ years, spice production declines because of increasing competition for water and nutrients, fungal infection due to overcrowding (Sampathu et al., 1984) and the reduced size and reproduction capability of corms. In a ten-year experiment, Grilli Caiola (2005) observed that corms left in the soil without management techniques continue producing daughter corms for up to 3-5 years and afterwards they degenerate and are no longer able to reproduce vegetatively. Di Crecchio (1960) and Tammaro (1990) reported similar conclusions. Every year in perennial crop techniques, daughter corms creep upwards by about $2 \mathrm{~cm}$ from the mother corm, and when they reach the soil surface they must be lifted and replanted.

In Navelli, where annual cultivation represents a strategy to avoid parasite infection, the corms are lifted up annually at the beginning of the summer, selected for size (diameter greater than $2.5 \mathrm{~cm}$ ), and checked for possible defects, such as rot, parasites, viruses, etc., before replanting (Tammaro, 1999). This continual selection of the best plants, even in the absence of sexual reproduction, may lead to the conservation of the highest morphological and productive characteristics. In annual cultivation used in Navelli after ploughing, a ridging hoe is used to prepare the "raised beds" about $30 \mathrm{~cm}$ from soil level, where 3-4 rows of corms, 20-30 cm apart, are placed with the apex in the upward direction. Raised beds allow better drainage of the soil and less effort in management techniques. In the highly humid environment of Navelli, perennial cultivation has been very unsuccessful due to the severe attack of root rot (Degli Espinosa, 1904).

\subsection{Corm planting (methods, rate and time) and harvesting}

Before planting, the soil should be completely cleared of weeds, ploughed at a depth of $25-30 \mathrm{~cm}$, and left to rest from a few weeks to the entire winter (Navelli). To avoid fungal infection, corms can be disinfected before planting by immersion for around 5 minutes in a benomil, captan or copper-based solution.

Sowing depth and spacing differ in annual and perennial crops. Sowing in perennial crops is deeper $(10-20 \mathrm{~cm})$ and wider spaced $(10-15 \mathrm{~cm}$ between corms and $20-25$ between rows) compared with annual crops ( $8-10 \mathrm{~cm}$ depth, $3-8 \mathrm{~cm}$ between corms and about 15 between rows), but shorter spacing is also used in intensive crop systems. Negbi et al. (1989) have shown that rooting and flowering are not affected by planting depth.

Sowing is commonly carried out by hand. Larger corm size has a well-documented positive effect on spice production in the same and following years (De Mastro and Ruta, 1993; De Juan et al., 2003; Negbi et al., 1989; Gresta et al., in press), namely, increasing corm size leads to a greater number and higher weight of replacement corms (Negbi et al., 1989; Lombardo et al., 2005). In unfavourable experimental site conditions in New Zealand, significant effects of corm size on flowering were detected only in the second crop season (McGimpsey et al., 1997). Generally, $2.5 \mathrm{~cm}$ is considered the smallest size below which corms need to be placed in a nursery for vegetative reproduction.

No univocal information is available for the most appropriate sowing time. In fact, like many other traditional crops, adopted agricultural techniques depend more on local practices passed on from generation to generation rather than scientific knowledge. Corms are sown in the second half of August in central Italy (Navelli), from the second half of June in Spain, between the middle of July and end of August in India, between May and September in Greece and between the end of August and the beginning of September in Morocco (Negbi, 1999). Recently, Gresta et al. (in press) showed that an earlier sowing time (end of July) results in a higher and better quality of saffron stigmas compared with a later one (end of August). In any case, corm dimensions and sowing time may affect daily flower production but not its duration (Fig. 4).

After leaf withering, corms are lifted up, generally from May to July, but also in September in Morocco, and kept in jute or hemp bags until planting. The external tunic can be 


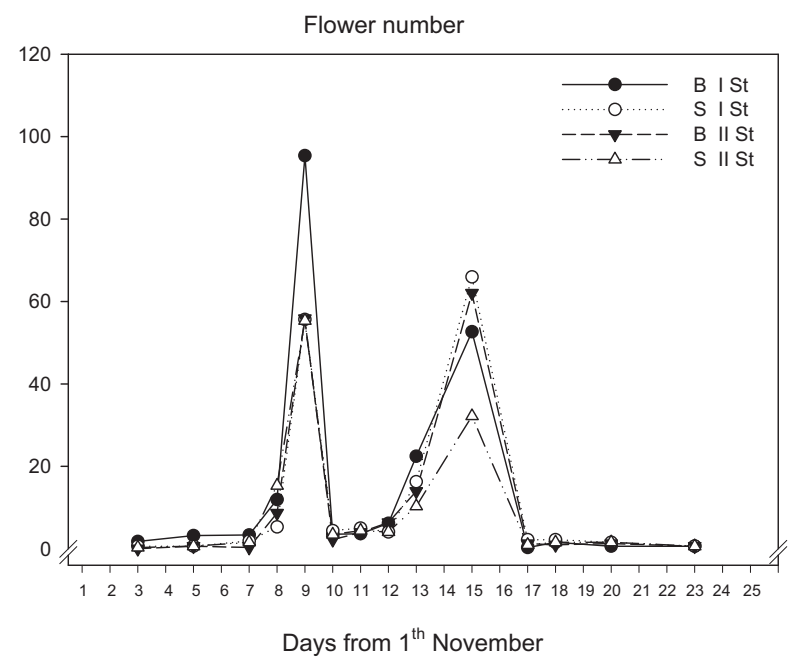

Figure 4. Daily flower production $\mathrm{N} \mathrm{m}^{-2} \mathrm{~d}^{-1}$ in relation to corm dimensions (Big: B and Small: S) and sowing time (I: early, II: late) (from Gresta et al., in press).

removed, leaving only the interior one. In spring, when corms pass to the natural summer rest, leaves can be cut and therefore this is a good moment for weed control.

\subsection{Crop rotation}

Saffron cultivation needs to be included in a crop rotation. No definitive information is available on the effect of the previous crop on saffron yield and quality, but traditionally between 3 and 8 years should pass before it is cultivated on the same soil. Tammaro (1999) reports that a decrease in stigma production and an increase in weed number have been observed when saffron was cultivated on the same soil. In central Italy, saffron is profitably rotated with legumes and wheat (Tammaro, 1999).

\subsection{Fertilising}

The application of about 20-30 tons per ha of organic manure is the most common fertilisation practice all over the world (Kooceki, 2004; Tammaro, 1990), while 40 units of $\mathrm{N}, 30$ units of $\mathrm{P}_{2} \mathrm{O}_{5}$ and 40 Units of $\mathrm{K}_{2} \mathrm{O}$ are applied in Greece (Goliaris, 1999). Mature horse and cow manure of about 25-30 t/ha, without any chemical fertilisation, determined good results in Navelli (Tammaro, 1999). On the contrary, incorporation of organic matter before planting did not improve saffron yields in New Zealand (McGimpsey et al., 1997). Behzad et al. (1992) found that $25 \mathrm{t} / \mathrm{ha}$ of cow manure significantly increased the dried stigma production in a soil with low organic content ( $0.3 \%$ in Organic Carbon), but had no effect in a soil with $1.0 \%$ O.C. They also observed that annual distribution of $50 \mathrm{~kg} / \mathrm{ha}$ of nitrogen increased saffron yields, and that phosphorus and potassium seems unnecessary. Sadeghi (1980) reports promising results of applying chemical fertiliser, while, in a three-year experiment in two sites in
Iran, Behnia et al. (1999) found contrasting results on nitrogen fertiliser, and no effect was shown by the application of phosphorus. Urea foliar fertilisation applied on saffron in winter (from January to March) resulted in a significant increase in flower number in a two-year experiment carried out in Iran (Hosseini et al., 2004).

\subsection{Irrigation}

Irrigation is not a necessary practice. Water requirements of saffron are low and can be satisfied by the scarce rainfall when cultivated in semi-arid conditions. Even in the Mediterranean environment, saffron is not watered in many cultivated areas (Sardinia, Abruzzo, Greece, etc.) (Tammaro, 1999; Skubris, 1990). Some authors (Koocheki, 2004; Mosaferi, 2001) report up to $3000 \mathrm{~m}^{3}$ flood irrigation per year in Iran and up to $500 \mathrm{~m}^{3} /$ ha in Morocco (Ait-Oubahou and El-Otmani, 1999). Experiments carried out in Greece (Skrubis, 1990) demonstrate that irrigation at the beginning of September resulted in an earlier onset of flowering, while irrigation at the end of September and during October determined an increase in production. Late irrigation could result in a worsening of the quality traits of saffron, especially if watered just before flowering. Certainly, the most crucial moment for irrigation is after summer to awaken the corms, but this coincides with autumn rains so, excepting a severe drought season, this may be considered unnecessary.

\subsection{Weed control}

Weeds are probably the main problem for saffron, since it is unable to compete, above all because of its very low height. Nevertheless, due to the short time between the corm planting and flowering, severe weed problems start the following spring in perennial cultivation. From flowering, weeds can be left to grow until May and then cut without damaging the crop when the saffron leaves wither.

Weeds are managed by hand in annual crops in Italy, while in perennial crops a good chemical control is generally achieved with $10 \mathrm{~kg} / \mathrm{ha}$ of Simazine (Gesatop 50\%) or Atrazina (Gesaprim 50\%) (Goliaris, 1999). In Iran, broad leaves are controlled with pre-emergence and post-emergence treatments of Sencor (Metribuzin) and narrow leaves with Gallant (Haloxy fopetoxy-ethyl) treatments after flower harvest. Pre-emergence treatments with Sonalan (Ethyl fluralin) are also used (Mollafilabi, 2004). During the summer rest, general herbicides such as Roundup (Glyphosate) or Buster (2,4-D, 2,4-DP) are applied.

Little research has been carried out on indirect weed control methods. Interesting results in reducing weeds with agronomic methods have been obtained with wood chips and sawdust mulch (Galigani and Garbati Pegna, 1999; McGimpsey et al., 1997; Zanzucchi, 1987) Experimental trials to control weeds with plastic films as dead mulch are on-going in southern Sicily (Sortino O., personal communication). 


\subsection{Harvesting and separating}

Gathering saffron flowers requires care and intensive manual labour: the flowers only grow a few centimetres aboveground and, depending on vegetative activity, might be surrounded by several leaves which must not be damaged otherwise daughter corms will not be produced. The flowers are harvested manually, generally by family members, by cutting the base of the flower stem with the fingernail. About 350-450 man hours are needed to harvest $1 \mathrm{~kg}$ of the spice, corresponding to between 200000 and 400000 stigmas, depending on the unitary weight. The saffron flower is highly ephemeral; given its very short life, it should be picked the same day of flowering and placed in baskets. The best practice is to pick the flower early in the morning each day, when the corolla is still closed, thereby preventing the stigmas from losing colour and quality, avoiding any sudden deterioration by wind or rain (Zanzucchi, 1987; Tammaro, 1990) and allowing a ready separation into their constituent parts. After harvest, stigmas must be separated from the tepals and stamen as soon as possible by opening the corolla and cutting the stigmas with the fingers below the branching where the style changes colour (from red to yellow).

\subsection{Mechanisation}

Tentative mechanisation procedures of some crop techniques in saffron have been carried out (Galigani, 1982, 1987; Galigani and Garbati Pegna, 1999), but it is a rather difficult crop. Lack of mechanisation in saffron is certainly due to the delicacy of corms and flowers, which require handling with care, but also to the considerable variation in size of corms. Other reasons are the cultivation of saffron in countries with very low manual labour costs and, on the contrary, the limited areas of land to which this crop is devoted in high labourcost countries. Planting requires regular and correctly oriented placement of the corms. A modified onion planter has been used to plant saffron, but the impossibility of placing the corms with the apex in the upward direction led to a delay in emergence and a decrease in production. In fact, the corm reduces emergence when the apex is not pointing upward. A potato planter was also tested, enabling more control for corm orientation, but resulting in lower production compared with the onion planter. A normal hoeing machine can be used to mechanise weed control, by adapting row distance, especially in the first year. Lower efficacy was obtained the following year with the increase in weeds and the rising of the daughter corms. During the rest period of the crop, flaming was also used with good results against young weeds (Galigani, 1987). If hysteranthy is manifested in saffron, flower harvesting can easily be mechanised with calibrated and adapted mowing or grasscutting machines, without cutting the leaves. No suitable results have been obtained for flower separation, while adapted bulb- and tuber-picking (such as a potato digger) can replace human labour successfully for corn lifting.

\subsection{Drying and storage of stigmas}

Drying and storage methods are very important because a poor undertaking of this procedure can completely compromise qualitative features of saffron (Carmona et al., 2005). According to the ISO norm, the moisture content may range between 10 and 12\% (ISO-3632, 2003). Many methods are used for the dehydration of saffron. Concerning Italian production, the stigmas are normally spread over a large area and dried at room temperature in the sunlight or with forced air. In Navelli, dehydration is traditionally carried out by placing the stigmas on a sieve $20 \mathrm{~cm}$ above a charcoal fire (Tammaro, 1999), while in Sardinia it is performed by drying stigmas in the sun or at room temperature (for several days) or in the oven at low temperature $\left(35-40{ }^{\circ} \mathrm{C}\right)$ in less time until moisture is reduced to $5-15 \%$. Saffron is sun-dried in India and Iran, and toasted over hot ashes in Spain, while it is dried slowly at 30$35{ }^{\circ} \mathrm{C}$ in dark rooms in Greece; therefore, many procedures are applied and, as is usual in such cases, there are still substantial disagreements over the best drying conditions (Raina et al., 1996; Carmona et al., 2005; Gregory et al., 2005).

Storage of saffron must be done in the dark and possibly in a modified atmosphere, since saffron pigments are light-, oxygen- and temperature-sensitive. The best way to store saffron spice is to keep it hermetically closed in darkened glass containers, and possibly at low temperature $\left(5-10{ }^{\circ} \mathrm{C}\right)$. (Mannino and Amelotti, 1977; Alonzo et al., 1990).

\subsection{Flower yield}

Yield is quite a difficult parameter to forecast in saffron: saffron yield is in fact a function of many agronomic, biological and environmental factors able to exert a great influence on production. As far as is known, production is strictly influenced by dimension (De Mastro and Ruta, 1993; Lombardo et al., 2005; Gresta et al., in press) and storage conditions of corms (Molina et al., 2004b), climatic conditions (Tammaro, 1990, 1999), sowing time (Gresta et al., in press), cultural techniques (annual or perennial), crop management (irrigation, fertilisation and weed control) and disease. Moreover, saffron production increases from the first to the third - fourth years of cultivation (McGimpsey et al., 1997). Generally, one hectare of saffron may produce $10-15 \mathrm{~kg}$ of dried stigmas, but it can range widely, depending on the abovementioned factors, from 2 to $30 \mathrm{~kg}$.

Yields of $2.5 \mathrm{~kg} / \mathrm{ha}$ are reported in Kashmir, India and Morocco (Bali and Sagwal, 1987; Sampathu et al., 1984) in rain-fed conditions, while it can reach $15 \mathrm{~kg} / \mathrm{ha}$ in Spain under irrigation and fertilisation (Sampathu et al., 1984; Dhar et al., 1988). In irrigated Moroccan areas, yields of about $2.5-6 \mathrm{~kg}$ are obtained (Ait-Oubahou and El-Otmani, 1999). In Iran, the average yield of saffron is around $5.4 \mathrm{~kg} / \mathrm{ha}$ (Behzad et al., 1992). In New Zealand, McGimpsey et al. (1997) reached yields of $24 \mathrm{~kg} / \mathrm{ha}$ of dried stigmas. A production of $29 \mathrm{~kg} / \mathrm{ha}$ was recorded in Navelli (Tammaro, 1999), but this is not comparable with the other yields because an annual cropping system is used and only the biggest corms are replanted every year. 


\subsection{Pests and disease}

The worst enemies of saffron are rodents and fungi (Tammaro, 1999; Goliaris, 1999). Moles, rats and rabbits can easily damage corms or eat leaves. Fungal attacks are mostly promoted by humid conditions. High moisture percentage together with high temperatures create ideal conditions for the rapid development and spread of nematodes and fungi (Fusarium, Penicillium, Rhizoctonia, etc.) and consequently corm rot. These conditions generally occur in the hot and rainy spring. Tammaro (1999) indicates that temperatures above $10-12{ }^{\circ} \mathrm{C}$ with rainy weather are a favourable climatic combination for the establishment of fungal disease on saffron. On the contrary, the hot and dry Mediterranean summer inhibits the spread of parasites. To avoid fungal infection, the best practices are crop rotation, the removal and burning of infected plants and corm treatments with anti-fungal products before planting, such as benomil or copper-based solution.

\section{QUALITATIVE CHARACTERISTICS OF STIGMAS}

\subsection{Chemistry of saffron: secondary metabolites}

Apart from the ubiquitous primary metabolites such as carbohydrates, minerals, fats and vitamins (Sampathu et al., 1984), the Crocus sativus L. plant contains a large number of components belonging to different classes of secondary metabolites, namely, carotenoids, monoterpenoids, flavonoids and anthocyanins. Carotenoids are the most characteristic and important components of saffron stigmas, responsible for the particular colorant features of this spice. They include both fat-soluble carotenoids such as lycopene, $\alpha$ - and $\beta$-carotene and zeaxanthin, and, mainly, the water-soluble $\mathrm{C}_{20}$ apocarotenoid, crocetin (8, ' ' -diapo-8, $8^{\prime}$-carotenedioic acid), and its ester derivatives, with one or more molecules of sugar, the trans crocetin ( $\beta$-D-digentibiosyl) ester being the most important and abundant component of this class (Lozano et al., 1999; Carmona et al., 2006c; Rychener et al., 1984) (Fig. 5). Amongst the other minor components belonging to this class, $\beta$-crocetin and $\gamma$-crocetin (Fig. 5), the mono- and dimethyl ester of crocetin, respectively, and mangicrocin (Fig. 6), an unusual xanthone-carotenoid glycosidic coniugate, have also been identified (Ghosal et al., 1989; Fernandez, 2004).

The other two typical features of saffron spice, namely the bitter taste and flavour, again derive from the carotenoid oxidation products: the bitter glucoside picrocrocin and safranal, respectively (Pfander and Schurterbeger, 1982) (Fig. 7). The first, picrocrocin, is a colourless glycoside, and is considered the main bitter principle of saffron, even though other components, such as flavonoids (vide infra), concur to give saffron's bitterness (Carmona and Alonso, 2004). Picrocrocin, according to the accepted biogenesis, should derive, like the members of the crocin family, from the enzymatic degradation of zeaxanthin; in turn, the transformation of picrocrocin gives the volatile safranal (Sampathu et al., 1984; Pfander and
Schurterbeger, 1982). The latter is the main volatile component of saffron, responsible for the particular aroma of this spice. Other typical volatile components of saffron are listed in Figure 8; all possess the same skeleton of safranal, and like this latter, are considered to derive from picrocrocin, even though the recent discovery of several new glycosides suggests that picrocrocin is not the sole glycosidic aroma precursor in saffron (Straubinger et al., 1997, 1998; Carmona et al., 2006c). However, it is worth underlining that the saffron essential oil is very prone to absorbing oxygen and becoming thick and brown, and because of this high instability, this volatile oil is not commercially available (Sampathu et al., 1984).

\subsection{Minor components of saffron}

Several minor components belonging to different classes of natural substances have been isolated from stigmas and other plant parts, mainly petals and corms. Terpenoids are the most frequently recovered components; the crocusatins (Fig. 8), present in stigmas and petals and showing a significant antityrosinase activity, represent a substantial group $(\mathrm{Li}$ and $\mathrm{Wu}$, $2002,2004)$. To the same class of substances, namely, terpenoids, belong several glycosidic derivatives (Fig. 8) which, as previously mentioned, are considered precursors of volatile saffron components alternative to picrocrocin (Straubinger et al., 1997, 1998). Moreover, a series of flavonoids, all glycosidic derivatives of kaempferol, have recently been characterised in the stigmas of saffron; these polyphenols probably concur together with picrocrocin to produce the bitter taste of saffron (Carmona et al., 2007). The scenario of the secondary metabolites from C. sativus is completed by some anthraquinones (Gao et al., 1999) and an anthocyanin (Maroto, 1950; Saito et al., 1960), isolated from corms and petals, respectively, and reported in Figure 9.

\subsection{Biosynthesis: argumentation on the synthetic pathways}

In 1982, it was suggested that the biogenesis of the colour, bitter taste and aroma principles of saffron derives from the bio-oxidative cleavage of the $\mathrm{C}_{40}$ oxygenated carotenoid zeaxanthin (Pfander and Schurterbeger, 1982), that leads to the formations, on one hand, of the $\mathrm{C}_{20}$ apocarotenoid pigments, and on the other, of picrocrocin and safranal (Fig. 9).

Crocetin and its related compounds have so far been detected only in some Crocus species, Crocus sativus L. being the most important one, and in the fruit of Gardenia jasminoides Ellis. This limited occurrence in nature prompted hypothesising that their biosynthetic pathway could be promoted by a specific enzymatic oxidation mechanism not involving well-known and ubiquitous lipoxygenases (Wu et al., 1999) or xanthine oxidase systems (Bosser and Belin, 1994). This enzyme, called CsZCD (zeaxanthin cleavage dioxygenase), in fact, specifically catalyses the synthesis of crocetin dialdehyde and hydroxy- $\beta$-cyclocitral (the latter further bio-modified 
<smiles>[R]OC(=O)C(C)=CC=CC(C)=CC=CC=C(C)C=CC=C(C)C(=O)O[R2]</smiles><smiles>[R]OC(=O)/C(C)=C/C=C/C(C)=C\C=C\C=C(C)\C=C\C=C(/C)C(=O)O[R2]</smiles>
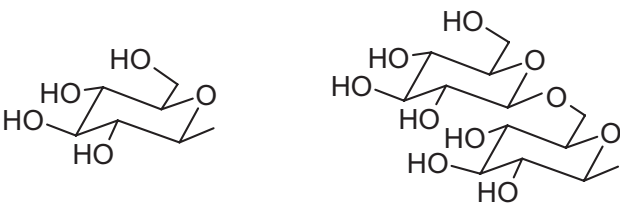

$\beta-D-G l u c o s e$

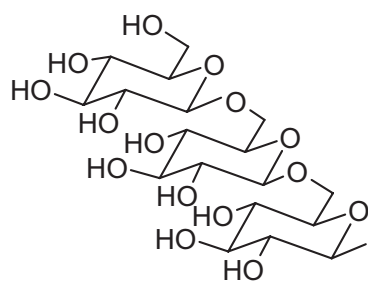

tri- $\beta$-D-Glucose

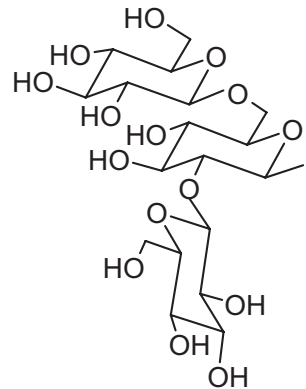

$\beta$-D-Neapolitanose

a) $R_{1}=R_{2}=\beta$-D-neapolitanoside (only all-trans)

f) $R_{1}=$ tri- $\beta$-D-glucoside, $R_{2}=\beta$-D-gentiobioside

b) $R_{1}=R_{2}=\beta$-D-gentiobioside

g) $R_{1}=\beta$-D-neapolitanoside, $R_{2}=\beta$-D-gentiobioside

c) $R_{1}=R_{2}=\beta$-D-glucoside

h) $R_{1}=\beta$-D-neapolitanoside, $R_{2}=\beta$-D-glucoside

d) $\mathrm{R}_{1}=\mathrm{R}_{2}=\mathrm{CH}_{3}$ ( $\gamma$-crocetin)

i) $R_{1}=\beta$-D-gentiobioside, $R_{2}=\beta$-D-glucoside

l) $R_{1}=\beta$-D-gentiobioside, $R_{2}=H$

m) $\mathrm{R}_{1}=\beta$-D-glucoside, $\mathrm{R}_{2}=\mathrm{H}$ (only all-trans)

n) $\mathrm{R}_{1}=\mathrm{CH}_{3}, \mathrm{R}_{2}=\mathrm{H}$ ( $\beta$-crocetin)

Figure 5. Crocetins and their glucoside ester (crocins) in saffron.

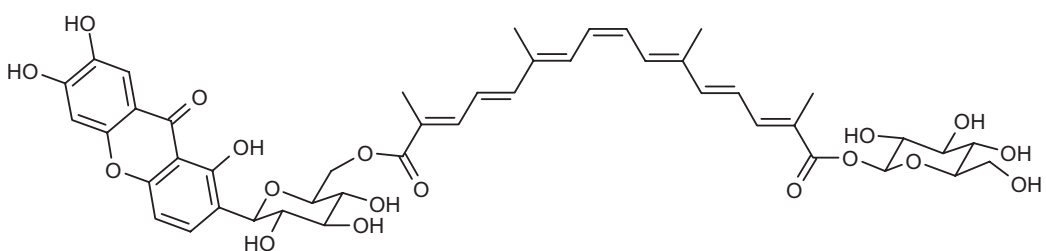

Mangicrocin

Figure 6. Mangicrocin, an unusual xanthone-carotenoid glycosidic conjugate.

into safranal) from zeaxanthin, and unlike other dioxygenases, CsZCD is expressed specifically in Crocus chromoplasts (Bouvier et al., 2003; Rubio et al., 2004; Castillo et al., 2005).

However, some controversies have recently been reported about the possible pathways proposed for crocetindialdehyde formation (see Fig. 9). An in-depth study of this topic, beyond the scope of this paper, has recently been tackled by Carmona and Alonso (2004), who conclude that the biosynthetic pathway of apocarotenoids in saffron still remains unknown.

Moreover, very recently Carmona et al. (2006b), starting from observations on some anomalies evidenced on the quantitative relationships between picrocrocin and safranal, have proposed an alternative pathway for the biosynthesis of saffron volatiles; according to their experimental results, safranal could be generated not only from picrocrocin but also from the crocetin chain by thermal degradation.

\subsection{Evaluation of quality: aroma, bitter taste and colouring power according to ISO norm}

Saffron quality is chemically defined as the sum of the colouring power of its pigments, the bitterness of picrocrocin, and the intensity of aroma due to the composition of its volatile oil. Chemical requirements for saffron filaments or powder are 


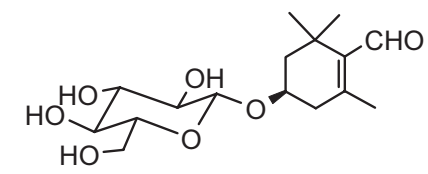

picrocrocin

2,6,6-Trimethyl-1,3-cyclohexadien-1-carboxyaldehyde (safranal)

3,5,5,-Trimethyl-2-cyclohexen-1-one (isophorone)

3,5,5,-Trimethyl-3-cyclohexene-1-one

2,6,6-Trimethyl-2-cyclohexene-1,4-dione

2,6,6-Trimethyl-1,4-cyclohexadien-1-carboxyaldehyde (safranal isomer)

4-Hydroxy-2,6,6-trimethyl-1-cyclohexene1-carboxaldehyde (HTCC)

2,6,6-Trimethylcyclohexane-1,4-dione

Figure 7. Picrocrocin and the main constituents of saffron aroma.

given by the ISO norm No. 3632-2 (2003), and presented in Table II.

This norm is based on a spectrophotometric test at three different reading wavelengths, namely, 440, 330 and 257 nanometers $(\mathrm{nm})$, corresponding to the maximum absorbance of crocetin esters, safranal and picrocrocin, respectively. The absorbance can be directly related to the concentration of the molecules present in solution, provided the latter is exactly the same for all samples, as must also be the other experimental conditions (temperature, path length, solvent used, physical form, etc.); the values obtained are an estimation of the quality of the sample submitted to the analysis. Different categories have been established (I-III), and are reported in Table II. Although the ISO norm for saffron quality is based on a test that is rapid, cheap and easily performed (only a spectrophotometer is needed for an accurate measurement), there are definitely several disadvantages: it is difficult to distinguish between authentic saffron and contaminants (the most recent adulterants have similar-shaped absorbance spectra to authentic natural pigments), and therefore to reliably assign a qual- ity category on the international market (Lozano et al., 1999; Zalacain et al., 2005b; Zougagh et al., 2005a).

\subsection{Evaluation of quality. Analytical methods in the analysis of saffron: chromatographic methods, UV-Vis (Ultaviolet Visible) and fluorescence detection}

Chromatography allows the separation of the pigments based on their different affinity to a stationary phase, packed on a column or present as a layer on an inert support, and a mobile phase.

In the last two decades, the most common chromatographic method used for the qualitative and even semi-preparative separation and analysis of saffron constituents was thin-layer chromatography (TLC), with silica gel used as the stationary phase and a mixture of highly polar solvents, namely, butanol, acetic acid and water as the mobile phase (Sampathu et al., 1984). More recently, reverse-phase high-performance liquid chromatography (RP-HPLC), coupled with a UV-Vis 
Selected monoterpenoidic compounds, crocusatins:

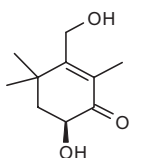<smiles>CC1(C)CC(=O)OC2(C)C(=O)OCC12</smiles><smiles>CCC(=O)C1=C(C)C[C@@H](O)CC1(C)C</smiles><smiles>CC1=C(C(O)CC(=O)O)C(C)(C)C[C@H](O)C1</smiles><smiles>CC1=C(CO)C(C)(C)C=C(O)C1=O</smiles>

Crocusatin $G$

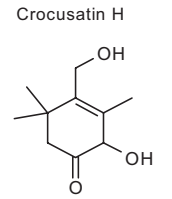

Crocusatin I<smiles>CC1=C(C=O)C(C)(C)[C@H](O)C(O)C1</smiles><smiles>CC1=C(C=O)C(C)(C)[C@@H](O)C(O)C1</smiles>

Crocusatin $\mathrm{K}$

Crocusatin L

Selected glycosidic aroma precuso

Selected polyphenols:
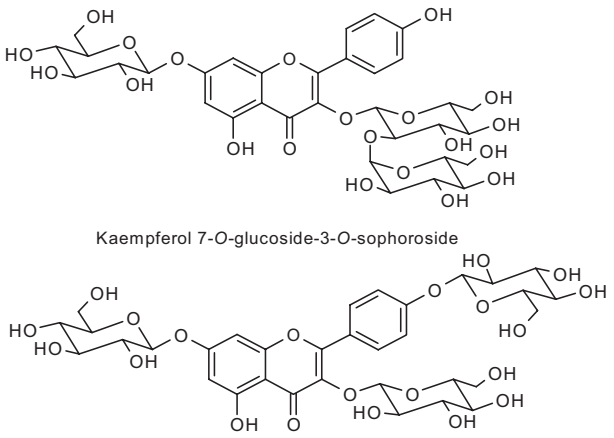

Kaempferol 3,7,4'-tri-O-glucoside

Selected antraquinones:<smiles>[R]c1cc(O)c2c(c1)C(=O)c1cc(OC)c(C(=O)O)c(C)c1C2=O</smiles>

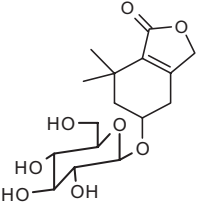

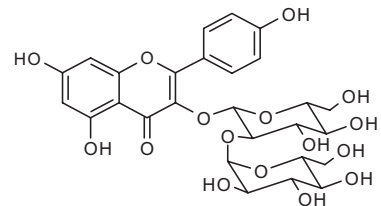

Kaempferol 3-O-sophoroside

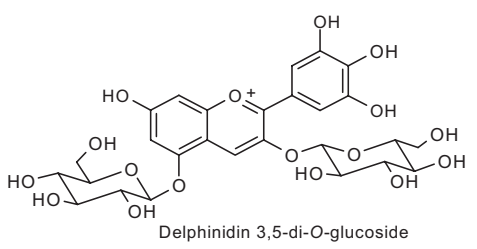

Delphinidin 3,5-di-O-glucoside

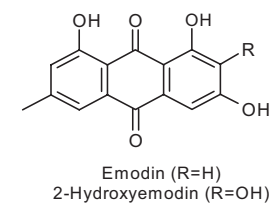

Figure 8. Minor secondary metabolites in saffron.

detector or, more often, a UV-Vis-DAD (Diode Array Detector) for non-volatile constituents (Caballero-Ortega et al., 2007), and Gas Chromatography (GC), with a mass spectrometer (MS) detector for the volatiles (Roedel and Petrzika, 1991; Narasimhan et al., 1992; Tarantilis and Polissiou, 1997) are the methods of choice, allowing the separation on an analytical level and the identification and quantification of the metabolites of interest. Due to the peculiar characteristics of the molecules belonging to the crocetin esters (high degree of conjugation and a certain rigidity of the terpenoid scaffold) fluorescence can also be used. The use of fluorimetry offers a better selectivity and sensitivity, though more precautions must be taken in sample handling (Trigoso and Stockert, 1995; Vickackaite et al., 2004).

\subsection{Other methods of analysis}

The development of new analytical techniques has prompted researchers to explore new methods to evaluate saffron quality and chemical composition, mainly in order to characterise chemotaxonomic connections between, for instance, the composition and geographical origin of the sample and/or composition and storage conditions. For example, two volatile components, namely, 3,5,5-trimethyl-2cyclohexenone (isophorone) and 2,6,6-trimethylcyclohexane1,4-dione (Fig. 7), together with the flavonoidic fraction and in particular kaempferol 3-sophoroside (Fig. 8), have been demonstrated to be useful in determining saffron's geographical origin (Carmona et al., 2006a, 2007). Furthermore, with 


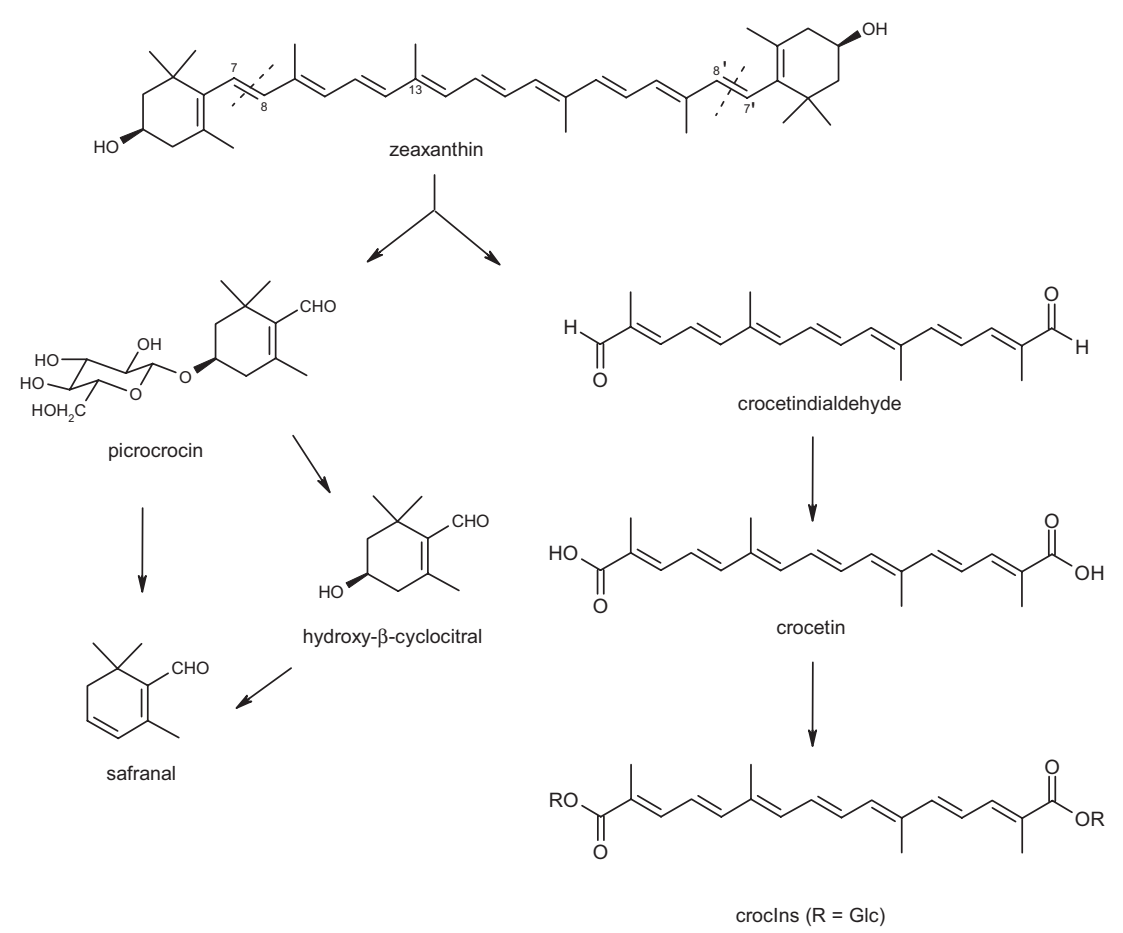

Figure 9. Generally accepted hypothesis for the generation of the secondary metabolites in saffron from a common precursor (zeaxanthin).

the advent of the holistic approach and metabolomics, there is the need for reliable, reproducible high-throughput devices to analyse large amounts of samples in order to build up libraries of spectra available for comparison.

Although RP-HPLC/UV-Vis-DAD (Reverse-Phase HighPerfomance Liquid Chromatography Ultraviolet Visible Diode Array Detector) is still the most widely used method, nearinfrared spectroscopy (NIR) (Zalacain et al., 2005b), nonaqueous CE (Capillary Electrophoresis) (Zougagh et al., $2005 \mathrm{~b})$ and proton nuclear magnetic resonance $\left({ }^{1} \mathrm{H}-\mathrm{NMR}\right)$ (Assimiadis et al., 1998; Tarantilis and Polissiou, 2004) have recently been developed with some success so far. Therefore, the exploitation of even more sophisticated analytical techniques with highly standardised procedures appears essential to guarantee the quality of the spice, to determine its geographical origin and to counter adulterations in order to evaluate and certify the best productions.

\subsection{Adulterations}

Adulteration of saffron dates back to the Middle Ages in Europe, and given its high value, the penalty for those adulterating this spice could be death (Safranshou Code). One of the first systematic collections of these fraudulent practices, most of them still in use, has been documented by Maish (1885). Adulteration is normally carried out with vegetable or synthetic substances, as well as with inorganic and organic matter. The most common adulteration is with different parts of the flower itself: styles, stamen, strips of the corolla; other vegetable adulterants often commonly used are: safflower, calendula, poppy, arnica, onion skins, turmeric, annatto, capsicum and stigmas of maize (Maish, 1885). Amongst the synthetic substances tartrazine, ponceau 2R, methyl orange, eosin and erythrosine are the synthetic dyes most frequently reported (Carmona and Alonso, 2004; Sampathu et al., 1984; Zalacain et al., 2005a). Saffron is also sometimes adulterated by the addition of oil, honey, glycerine, solutions of potassium or ammonium nitrate, and dry meat fibres (Sampathu et al., 1984).

\subsection{Biological properties: use in folk medicine and in modern clinical trials}

The use of saffron goes back to ancient Mediterranean civilisations (Greece, Egypt and Rome), as well as many areas of the Middle and Far East. Its main and common use is to give colour, flavour and aroma to food, and to a lesser extent it is reported to be used as a dye and ingredient of perfumes. The use of saffron as a food additive is so widespread in the world that almost every national cuisine comprises a dish strongly characterised by saffron, namely, Spanish paella, Italian risotto, French bouillabaisse, Iranian plov, Azerbaijani paklova, etc. In central Sicily, for example, saffron is used to produce ' $\mathrm{Pi}$ acentinu Ennese', an old and traditional cheese, whose taste, colour and flavour is strongly influenced by this spice (Horne et al., 2005).

As a medicinal plant saffron is still used in traditional medicine in several countries (Russia, India and Iran) (Mathew, 1982; Tamarro, 1990), and from a toxicological point of view it can be considered safe since its $\mathrm{LD}_{50}=$ $20 \mathrm{~g} / \mathrm{kg}$ (Bisset, 1994). It has traditionally been considered as an anodyne, antidepressant, respiratory decongestant, 
Table II. ISO norm for the quality of saffron.

\begin{tabular}{|c|c|c|c|}
\hline \multirow{2}{*}{ Test method } & \multirow{2}{*}{ Characteristic } & \multicolumn{2}{|c|}{ Requirements } \\
\hline & & Filaments & Powder \\
\hline ISO/TS 3632-2:2003, art. 7 & Moisture and volatile matter, \% $(\mathrm{m} / \mathrm{m})$, max & 12 & 10 \\
\hline $\begin{array}{l}\text { ISO 928:1997, art. } 8 \& \text { \& } \\
\text { ISO/TS 3632-2:2003, art. } 12\end{array}$ & Total ash, \% (m/m), $\max$ & 8 & 8 \\
\hline \multirow{3}{*}{$\begin{array}{l}\text { ISO 930:1997, art. } 7 \& \text { ISO/TS } \\
\text { 3632-2:2003, art. } 13\end{array}$} & \multirow{3}{*}{$\begin{array}{l}\text { Acid-insoluble ash, \% }(\mathrm{m} / \mathrm{m}) \text {, on dry basis, max: } \\
\text { Categories I and II } \\
\text { Categories III and IV }\end{array}$} & & \\
\hline & & 1 & 1 \\
\hline & & 1.5 & 1.5 \\
\hline ISO 941:1980, art. 7 & $\begin{array}{l}\text { Solubility in cold water, \% }(\mathrm{m} / \mathrm{m}) \text {, } \\
\text { on dry basis, } \max \end{array}$ & 65 & 65 \\
\hline \multirow{5}{*}{ ISO/TS 3632-2:2003, art. 14} & \multirow{5}{*}{$\begin{array}{l}\text { Bitterness, expressed as direct reading of the } \\
\text { absorbance of picrocrocine, on dry basis, min: } \\
\text { Category I } \\
\text { Category II } \\
\text { Category III }\end{array}$} & & \\
\hline & & & \\
\hline & & 70 & 70 \\
\hline & & 55 & 55 \\
\hline & & 40 & 40 \\
\hline \multirow{4}{*}{ ISO/TS 3632-2:2003, art. 14} & \multirow{4}{*}{$\begin{array}{l}\text { Safranal, expressed as direct reading of the } \\
\text { absorbance at about } 330 \mathrm{~nm} \text {, on dry basis: } \\
\min \\
\max \end{array}$} & & \\
\hline & & & \\
\hline & & 20 & 20 \\
\hline & & 50 & 50 \\
\hline \multirow{6}{*}{ ISO/TS 3632-2:2003, art. 14} & \multirow{6}{*}{$\begin{array}{l}\text { Colouring strength, expressed as direct } \\
\text { reading of the absorbance of crocine at } \\
\text { about } 440 \mathrm{~nm} \text {, on dry basis, min: } \\
\text { Category I } \\
\text { Category II } \\
\text { Category III }\end{array}$} & & \\
\hline & & & \\
\hline & & & \\
\hline & & 190 & 190 \\
\hline & & 150 & 150 \\
\hline & & 100 & 100 \\
\hline ISO/TS 3532-2:2003, art. 14 & Synthetic hydrosoluble acid dyes & 0 & 0 \\
\hline
\end{tabular}

antispasmodic, aphrodisiac, diaphoretic, emmenagogue, expectorant and sedative. It was used in folk medicine as a remedy against scarlet fever, smallpox, colds, asthma, eye and heart disease, and cancer (Abdullaev, 2002). Saffron can also be used topically to help clear up sores and to reduce the discomfort of teething infants (Abdullaev and Espinosa-Aguirre, 2004).

Among the secondary metabolites present in saffron the ester derivatives of crocetin, together with safranal, are nowadays the most studied to evaluate their biological activity. Recent data show that saffron possesses tyrosinase inhibitory ( $\mathrm{Li}$ and $\mathrm{Wu}, 2002,2004)$, anticonvulsant (Hosseinzadeh and Khosravan, 2002), antinflammatory (Hosseinzadeh and Younesi Hani, 2002) and mutagenic activities (Abdullaev and Espinosa-Aguirre, 2004), and cytotoxic and antigenotoxic effects (Abdullaev et al., 2003), as well as antiamyloidogenic activity in Alzheimer's disease (Papandreou et al., 2006). Cancer chemopreventive and tumoricidal properties of saffron extracts are worth special mention, as scientific research in the last 5 years (2001-2006) has focused on this specific topic, with numerous encouraging results supported by in vitro and in vivo assays (Abdullaev, 2002; Ahmad et al., 2005; Hosseinzadeh et al., 2005; Konoshima and Takasaki, 2003; Magesh et al., 2006; Ochiai et al., 2004; Soeda et al., 2005).

\section{CONCLUSIONS AND PROSPECTS OF SAFFRON}

From an agronomic point of view, saffron is a very unusual plant for its agrological and ecophysiological character- istics. It is unable to produce seeds and multiplies by means of a subterranean stem. It does not exist in the wild state and only very recent studies have been addressed to the individuation of ancestors so that we have not yet had the possibility of acquiring information from these for improving the crop. Saffron has a reverse biological cycle compared with the majority of cultivated and spontaneous plants: flowering first in October-November, then vegetative development until May, which means that the vegetative development is not directly important for production of stigmas, but for the production of new corms. The plant itself has an annual cycle, but the crop is perennial, precisely owing to its vegetative multiplication. Saffron has a low water use and a very low harvest index (Fernandez, 2004). Above all, the parts harvested for production are the stigmas, from which a very expensive spice is obtained, probably a unique case in an agronomic context. Last but not least, saffron cultivation has been neglected for many decades by farmers, who have relegated it to adverse soil and climate conditions, and by research, which has led to a lack of innovation. All these reasons should induce revision of the most common agronomic knowledge for an effective revaluation of the crop. Synergy between the empirical knowledge of producers and scientific knowledge is able to generate new agronomic knowledge, especially in poorly-known crops, such as saffron, in which technical management represents a major hindrance to development (Girard and Navarrete, 2005).

At the moment, saffron's future is rather uncertain: major productions come from the Middle East and South Asia with a low price, but often without quality control. This may mean 
that without changes in crop techniques and without the introduction of quality identification methods, many areas of saffron cultivation in Europe will decrease rapidly in the next few years.

A significant input to high quality saffron production could come from the wide sector of functional foods, nutraceuticals and dietary supplements. The growing interest of consumers and industry in the development of new products endowed with functional features, or health benefits, is testified by market expenditure analyses, which report that $\$ 20.5$ billion were spent on dietary supplements during 2004 in the USA (Burdock et al., 2006). Saffron has many qualities to find a suitable place within this field. Consumer interest in saffron is growing, for example, especially in the USA and UK, though largely attracted by the low price and not by the quality.

According to Grilli Caiola (2004) and Fernandez (2004), increasing saffron production and quality can be achieved by means of plants with more flowers per plant, flowers with a higher number of stigmas, increased stigma size or stigmas with a greater amount of dye and aroma. The sterility of saffron limits the application of conventional breeding approaches for its further improvement. Vegetative multiplication, in fact, offers the major advantage of maintaining the plant's genetic traits, but does not allow any genetic improvement. In fact, corm multiplication does not induce genome variations. Traditional plant breeding techniques, based on a massive selection of the best samples among natural or cultivated populations, is restricted to searching for a quote of variability deriving from some rare mutations. Even though no genetic differences were detected with RAPD methodology, morphological difference was observed (Grilli Caiola, 2004). At the moment, we cannot exclude the possibility that differences may still exist among saffron from different places; maybe a deeper genomic analytical determination will soon be able to reveal variability. Genetic improvement in saffron should mainly be addressed to breeding with wild ancestral species and to the selection of spontaneous or induced mutations. The characteristic infertility of $C$. sativus intraspecific pollination and its fertility with pollen from other Crocus species suggests a possible breeding programme of hybridisation with $C$. thomasii, a closely related, highly fertile and vital wild species common in southern Italy (Chichiriccò, 1999). Integration of saffron with wild Crocus species can lead to fertility, resistance to pathogenic fungi and improvement in saffron spice quality (Negbi et al., 1989). Naturally, pollination of saffron with a different pollen donor species (interspecific pollination) will generate a seed with different genetic traits from the original triploid saffron. Moreover, in Navelli, the selection of corms carried out each year has produced a significant "genetic pool", which must be studied above all with respect to corm dimensions and disease resistance (traits for which the selection is made).

Multistigma flowers have been found by many authors (Estilai, 1978; Dhar et al., 1988; Gresta et al., unpublished data), but unfortunately they are not stable and prove useless for cultivation. An artificial source of variability in order to obtain some improvements in saffron yield, even if no interesting results have been obtained, can be considered with colchicine (Zaffar et al., 2004) or physical irradiation (Khan, 2004).

More promising results may derive from biotechnological tools, the improvement of agronomic management and individuation of areas in which saffron is able to achieve the highest results (Fernandez and Escribano, 2000). Promoting cultivation in areas with dry Mediterranean summers, in which fungal infections are less widespread and where perennial cultivation is realisable, avoiding parasite attacks and weed overcrowding, may be a possible strategy.

The spread of saffron cultivation should also undergo mechanisation. Achieving a total mechanisation in saffron is almost impossible, but suitable tools and existing machinery already available for other crops can certainly reduce manual labour in saffron and accelerate some operations, thereby reducing production costs. Improvement in research on mechanisation of saffron crop techniques can lead to interesting results, but the more delicate operations are very far from being mechanised and should be done by hand. Hard labour requirements are partially recovered by the high price of the spice, with the drawback of a very small market. Pure mechanisation studies have obtained the first results on sowing and lifting of corms, but not on flower picking. Instead, what might make these studies more applicable would be the adaptation of the crop to mechanisation. In this context, a central role in any developmental programme could be played by the typical feature of hysteranthy of the saffron corm. Genetic (selection) and biological (storing conditions) studies devoted to hysteranthy able to prolong the leaf appearance at the complete end of flowering, could prove an important step towards mechanisation. Achievement of hysteranthy in saffron cultivation would mean the possibility of mechanising flower harvest, thus avoiding cutting leaves, notably reducing production costs and the price of the spice, giving saffron cultivation a major boost. Moreover, the use of appropriate crop techniques such as plant density, sowing time, use of living or dead mulch, etc., can lead to successful results, the spreading of cultivation and reduced price.

High quality saffron production from selected areas with appropriate and safe management techniques cannot compete in the world market with the saffron from low-cost manual labour-intensive countries, but must be addressed towards a potential niche market of high-level quality. To reach it, more attention should be focused on using modern techniques and the evaluation and promotion of saffron quality. The process must be accompanied by traceability, quality marking in order to attract more consumer interest, the adoption of organic agriculture management techniques (no pesticide and chemical fertilisation) and the reduction in manual labour. In saffron, the commercial products (stigmas) are not storage structures as in most cultivated plants, so an increase in nutrients in the soil is not directly linked to an increase in stigma weight. Certainly, a fertile soil is the basis for good saffron production, but organic manure represents the best support for saffron, especially under non-irrigated conditions, supplying nutrients, but above all, improving soil moisture and soil structure. In very nutrient-poor soil, limited chemical fertilising can be adopted. 
The biological and agronomical traits of saffron (autumn flowering, overcoming adverse season by corms, very low fertiliser requirements and good adaptation to poor soil) make it an alternative plant for low-input agriculture, able to offer good production in sustainable agricultural systems. It may be considered a viable alternative crop for marginal lands, especially where low water availability severely limits the cultivation of many crops. Certainly, the improvement and, above all, the diffusion of knowledge on this species will encourage farmers in low-fertility areas to increase their income with saffron cultivation.

Acknowledgements: We are grateful to Prof. Maria Grilli Caiola and to Prof. Antonia Cristaudo for their useful suggestions on genetic and botanical features.

\section{REFERENCES}

Abdullaev F.I. (2002) Cancer chemopreventive and tumoricidal properties of saffron (Crocus sativus L.), Exp. Biol. Med. 227, 20-25.

Abdullaev F.I., Espinosa-Aguirre J.J. (2004) Biomedical properties of saffron and its potential use in cancer therapy and chemoprevention trials, Cancer Detect. Prev. 28, 426-432.

Abdullaev F.I., Riveron-Negrete L., Caballero-Ortega H., Herdandez J.M., Perez-Lopez I., Pereda-Miranda R., Espinosa-Aguirre J.J. (2003) Use of in vitro assays to assess the potential antigenotoxic and cytotoxic effects of saffron (Crocus sativus L.), Toxicol. Vitro 17, 731-736.

Ahmad A.S., Ansari M.A., Ahmad M., Muzamil S.S., Yousuf S., Hoda M.N., Islam F. (2005) Neuroprotection by crocetin in a hemiparkinsonian rat model, Pharmacol. Biochem. Be. 81, 805-813.

Ait-Oubahou A., El-Otmani M. (1999) Saffron cultivation in Morocco, in: Negbi M. (Ed.), Saffron: Crocus sativus L., Harwood Academic Publishers, Australia, pp. 87-94.

Alonso G.L., Varon R., Gomez R., Navarro F. Salinas M.R. (1990) Autooxidation in saffron at $40{ }^{\circ} \mathrm{C}$ and $75 \%$ humidity, J. Food Sci. 55, 595-596.

Alvarez-Orti M., Gomez-Gomez L., Rubio A., Escribano J., Pardo J., Jimenez F., Fernandez J.A. (2004) Development and Gene Expression in saffron corms, Proceedings of the First International Symposium on Saffron Biology and Biotechnology, Acta Hort. 650, 141-153.

Assimiadis M.K., Tarantilis P.A., Polissiou M.G. (1998) UV-Vis, FTRaman, and ${ }^{1} \mathrm{H}$ NMR spectroscopies of cis-trans carotenoid from saffron (Crocus sativus), Appl. Spectrosc. 52, 519-522.

Azizbekova N.S.H., Milyaeva E.L. (1999) Saffron in cultivation in Azerbaijan, in: Negbi M. (Ed.), Saffron: Crocus sativus L., Harwood Academic Publishers, Australia, pp. 63-71.

Bali A.S., Sagwal S.S. (1987) Saffron - a cash crop of Kashmir Agr. Situation India, pp. 965-968.

Basker D., Negbi M. (1983) The use of Saffron, Eco. Bot. 37, 228-236.

Battaglia E. (1963) Apomixis, in: Maheshwari P. (Ed.), Recent advances in the embryology of angiosperms, International Society of Plant Morphology, University of Dehli.

Behnia M.R., Estilai A., Ehdaie B. (1999) Application of fertilizer for increased saffron yield, J. Agr. Crop Sci. 182, 9-15.

Behzad S., Razavi M., Mahajeri M. (1992) The effect of mineral nutrients (N, P, K) on saffron production, Acta Hort. 306, 426-430.
Bisset N.G. (1994) Herbal drugs and phytopharmaceuticals, Medpharm Scientific Publications, Stuttgart.

Bosser A., Belin J.M. (1994) Synthesis of $\beta$-ionone in an aldehyde/xanthine oxidase $/ \beta$-carotene system involving free radical formation, Biotechnol. Progr. 10, 129-133.

Bouvier F., Suire C., Mutterer J., Camara B. (2003) Oxidative remodeling of chromoplast carotenoids: identification of the carotenoid dioxygenase CsCCD and CsZCD genes involved in Crocus secondary metabolite biogenesis, Plant Cell 15, 47-62.

Brandizzi F., Grilli Caiola M. (1998) Flow cytometric analysis if nuclear DNA in Crocus sativus and allies (Iridacee), Plant. Syst. Evol. 211, 149-154.

Brighton C.A. (1977) Cytology of Crocus sativus L. and its allies (Iridaceae), Plant Syst. Evol. 128, 137-157.

Burdock G.A., Carabin I.G., Griffiths J.C. (2006) The importance of GRAS to the functional food and nutraceutical industries, Toxicology 221, 17-27.

Caballero-Ortega H., Pereda-Miranda R., Abdullaev F.I. (2007) HPLC quantification of major active components from 11 different saffron (Crocus sativus L.) sources, Food Chem. 100, 1126-1131, and references therein.

Carmona M., Alonzo G.L. (2004) A new look at saffron: mistakes beliefs, Proceedings of the First International Symposium on Saffron Biology and Biotechnology, Acta Hort. 650, 373-391.

Carmona M., Zalacain A., Pardo J.E., Lòpez E., Alvarruiz A., Alonso G.L. (2005) Influence of different drying and aging conditions on saffron constituents, J. Agr. Food Chem. 53, 3974-3979.

Carmona M., Martínez J., Zalacain A., Rodríguez-Méndez M.L., De Saja J.A., Alonso G.L. (2006a) Analysis of saffron volatile fraction by TD-GC-MS and e-nose, Eur. Food Res. Technol. 223, 96-101.

Carmona M., Zalacain A., Salinas M.R., Alonso G.L. (2006b) Generation of saffron volatiles by thermal carotenoid degradation, J. Agr. Food Chem. 54, 6825-6834.

Carmona M., Zalacain A., Sanchez A.M., Novella J.L., Alonso G.L. (2006c) Crocetin esters, picrocrocin and its related compounds present in Crocus sativus stigmas and Gardenia jasminoides fruits. Tentative identification of seven new compounds by LC-ESI-MS, J. Agr. Food Chem. 54, 973-979.

Carmona M., Sánchez A.M., Ferreres F., Zalacain A., Tomás-Berberán F., Alonso G.L. (2007) Identification of the flavonoid fraction in saffron spice by LC/DAD/MS/MS: comparative study of samples from different geographical origin, Food Chem. 100, 445-450.

Castillo R., Fernandez J.A., Gomez-Gomez L. (2005) Implications of carotenoid biosynthetic genes in apocarotenoid formation during the stigma development of Crocus sativus and its closer relatives, Plant Physiol. 139, 674-689.

Chichiriccò G. (1984) Karyotype and meiotic behaviour of the triploid Crocus sativus L., Caryologia 37, 233-239.

Chichiriccò G. (1996) Intra- and interspecific reproductive barriers in Crocus (Iridacee), Plant. Syst. Evol. 201, 83-92.

Chichiriccò G. (1999) Sterility and perspectives for genetic improvement of Crocus sativus L., in: Negbi M. (Ed.), Saffron, Harwood Academic Publishers, Amsterdam, pp. 127-135.

Chichiriccò G., Grilli Caiola M. (1984) Crocus sativus pollen tube growth in intra- and interspecific pollination, Caryologia 37, 115-125.

Chio-Sang T. (1996) Effect of planting depth and existence of tunic on growth and flowering in Freesia forcing, J. Korean Hortic. Sci. 37, $57-581$.

Dafni A., Shmida A., Avishai M. (1981) Leafless autumnal flowering geophytes in the Mediterranean region. Photographical, ecological and evolutionary aspects, Plant. Syst. Evol. 173, 181-193. 
De Juan J.A., Moya A., Lopez S., Botella O., Lopez H., Muòoz R. (2003) Influencia del tamaòo del cormo y la densidad de plantación de la producción de cormos de Crocus sativus L., ITEA 99, 169-180.

De Mastro G., Ruta C. (1993) Relation between corm size and saffron (Crocus sativus L.) flowering, Acta Hort. 344, 512-517.

Debussche M., Garnier E., Thompson J.D. (2004) Exploring the causes of variation in phenology and morphology in Mediterranean geophytes: a genus-wide study of Cyclamen, Bot. J. Linn. Soc. 145, $469-484$.

Degli Espinosa G. (1904) Lo zafferano, Coltivazione e commercio, L'Aquila.

Dhar A.K., Sapru R., Rekha K. (1988) Studies on saffron in Kashmir. 1. Variation in natural population and its cytological behaviour, Crop Improv. 15, 48-52.

Di Crecchio R. (1960) Lo zafferano, L'Italia Agricola N. 6, Ramo Editoriale degli Agricoltori (Ed.), Roma, p. 23.

Ehsanzadeh P., Yadollahi A.A., Maibodi A.M.M. (2004) Productivity, growth and qualità attributes of 10 Iranian saffron accession under climatic conditios of Chahar-Mahal Bakhtiari, Central Iran, Acta Hort. 650, 183-188.

Estilai A. (1978) Variability in saffron (Crocus sativus L.), Experientia 34,725 .

Fernández J.A. (2004) Biology, biotechnology and biomedicine of saffron, Recent Res. Dev. Plant Sci. 2, 127-159.

Fernández J.A., Escribano Martínez J. (2000), Biotecnología del azafrán, Ed. Universidad de Castilla, La Mancha, Cienc. Téc. 31 Cuenca.

Galigani P.F. (1982) Progetto piante officinali: relazione dell'attività svolta dall'Unità Operativa dell'Istituto di Meccanica Agraria Meccanizzazione della Facoltà di Agraria dell'Università di Firenze nel II anno di ricerca 1981-1982, unpublished.

Galigani P.F. (1987) La meccanizzazione delle colture di salvia, lavanda, zafferano e genziana, Proceedings of the Conference on the "Coltivazione Piante officinali", Trento 9-10 ottobre (1986), pp. 221-235.

Galigani P.F., Garbati Pegna F. (1999) Mechanized saffron cultivation including harvesting, in: Negbi M. (Ed.), Saffron: Crocus sativus L., Harwood Academic Publishers, Australia, pp. 115-126.

Gao W.-Y., Li Y.-M., Zhu D.-Y. (1999) New anthraquinones from the sprout of Crocus sativus, Acta Bot. Sin. 41, 531-533.

Ghaffari S.M. (1986) Cytogenetic studies of cultivated Crocus sativus (Iridacee), Plant Syst. Evol. 153, 199-204.

Ghosal S., Singh S.K., Battacharya S.K. (1989) Mangicrocin, and adaptogenic xanthone-carotenoid glycosidic conjugate from saffron, J. Chem. Res. - S 3, 70-71.

Girard N., Navarrete M. (2005) Quelles synergies entre connaissances scientifiques et empiriques? L'exemple des cultures du safran et de la truffe, Nat. Sci. Soc. 13, 33-44.

Goliaris A.H. (1999) Saffron cultivation in Greece, in: Negbi M. (Ed.), Saffron: Crocus sativus L., Harwood Academic Publishers, Australia, pp. 73-85.

Gregory M., Menary R.C., Davies N.W. (2005) Effect of drying temperature and air flow on the production and retention of secondary metabolites in saffron, J. Agr. Food Chem. 53, 5969-5975.

Gresta F., Lombardo G.M., Ruberto G., Siracusa L., Effect of mother corm dimension and sowing time on stigmas yields, daughter corms and qualitative aspects of saffron (Crocus sativus L.) in Mediterranean environment, J. Sci. Food Agric., in press.

Grilli Caiola M. (1999) Reproduction biology in saffron and its allies, in: Negbi M. (Ed.), Saffron, Amsterdam, Harwood Academic Publishers, pp. 31-52.
Grilli Caiola M. (2004) Saffron reproductive biology, Acta Hort. 650, 25-37.

Grilli Caiola M. (2005) Embryo origin and development in Crocus sativus L. (Iridacee), Plant Biosyst. 139, 335-343.

Grilli Caiola M., Chichiriccò G. (1991) Structural organization of saffron (Crocus sativus L.) pistil, Israel J. Bot. 40, 199-207.

Grilli Caiola M., Di Somma D., Lauretti P. (2001) Comparative study on pollen and pistil of Crocus sativus L. (Iridaceae) and its allied species, Ann. Bot., Roma 1, 93-103.

Grilli Caiola M., Caputo P., Zanier R. (2004) RAPD analysis in Crocus sativus L. accessions and related Crocus species, Biol. Plantarum $48,375-380$.

Halevy A.H. (1990) Recent advances in control of flowering and growth habit of geophytes, Acta Hort. 266, 35-42.

Horne J., Carpino S., Tumminello L., Rapisarda T., Corallo L., Licitra G. (2005) Differences in volatiles, and chemical microbial and sensory characteristics between artisanal and industrial Piacentinu Ennese Cheeses, Int. Dairy J. 15, 605-617.

Hosseini M., Sadeghiand B., Aghamiri S.A. (2004) Influence of foliar fertilization on yield of saffron (Crocus sativus L.), Acta Hort. 650, 207-209.

Hosseinzadeh H., Khosravan V. (2002) Anticonvulsant effects of aqueous and ethanolic extracts of Crocus sativus L. stigmas in mice, Arch. Intern. Med. 581, 44-47.

Hosseinzadeh H., Younesi Hani M. (2002) Antinociceptive and anti-inflammatory effects of Crocus sativus L. stigma and petal extracts in mice, BMC Pharmacol. 2, 7 (www.biomedcentral.com/bmcpharmacol).

Hosseinzadeh H., Sadeghnia H.R., Ziaee T.D. (2005) Protective effect of aqueous saffron extract (Crocus sativus L.) and crocin, its active constituent, on renal ischemia-reperfusion-induced oxidative damage in rats, J. Pharm. Sci. 8, 387-393.

Ingram J.S. (1969) Saffron (Crocus sativus L.), Trop. Sci. 11, 177-184.

International Trade Centre, UNCTAD/WTO (2006) World Markets in the Spice Trade 2000-2004, Geneva, ITC, 2006, vi, 111 p.

ISO-3632-2-2003 (2003) Part 1: Specification, Part 2: Test Methods, International Organisation for Standardization, Geneva.

Kalesi M., Behboodi B.Sh., Ebrahimzadeh H. (2004) Development and contraction of contractile roots in Crocus sativus, Acta Hort. 650, $55-58$.

Khan I.A. (2004) Induced mutagenic variability in saffron (Crocus sativus L.), Acta Hort. 650, 281-283.

Konoshima T., Takasaki M. (2003) Anti-carcinogenic activities of natural pigments from beet root and saffron, Foods Food Ingredients J. Japan 208 615-622.

Koocheki A.A. (2004) Indigenous knowledge in agriculture with particular reference to saffron production in Iran, Acta Hort. 650, 175-182.

Li C.-Y., Wu T.-S. (2002) Constituents of the Stigmas of Crocus sativus and Their Tyrosinase Inhibitory Activity, J. Nat. Prod. 65, 1452-1456.

Li C.-Y., Wu T.S. (2004) Antityrosinase principles and constituents of the petals of Crocus sativus, J. Nat. Prod. 67, 437-440.

Lombardo G., Gresta F., La Malfa G., Scoto A. (2005) Primi risultati sulla coltivazione dello zafferano nella collina interna siciliana, Proceedings of the first congress on "Piante mediterranee", Agrigento, 7-8 ottobre, Italy.

Lozano P., Castellar M.R., Simancas M.J., Ibora J.L. (1999) A quantitative high-performance liquid chromatographic method to analyze commercial saffron (Crocus sativus L.) products, J. Chromatogr. A 830, 477-483. 
Magesh V., Singh J.P.V., Selvendiran K., Ekambaram G., Sakthisekaran D. (2006) Antitumour activity of crocetin in accordance to tumor incidence, antioxidant status, drug metabolizing enzymes and histopathological studies, Mol. Cell. Biochem. 287, 127-135.

Maish J.M. (1885) On the adulteration of saffron, The Analyst 200-203.

Manganaro G. (2001) Tra archeologia ed epigrafia: due note, Z. Papyrologie Epigraphik 137, 189-196.

Mannino S., Amelotti G. (1977) Determinazione dell'umidità ottimale di conservazione dello zafferano, Riv. Soc. Ital. Sci. Aliment. 2, 9598.

Maroto A.L. (1950) Natural anthocyanin pigments, Rev. Real Acad. Sci. Exact Fis. Nat (Madrid) 44, 79, CA 46, 581.

Mathew B. (1977) Crocus sativus L. and its allies (Iridaceae), Plant Syst. Evol. 128, 89-103.

Mathew B. (1982) The Crocuses: a revision of the genus Crocus, B.T. Batsford, London.

Mathew B. (1999) Botany, taxonomy and cytology of Crocus sativus L. and its allies, in: Negbi M. (Ed.), Saffron, Harwood Academic Publishers, Amsterdam.

McGimpsey J.A., Douglas M.H., Wallace A.R. (1997) Evaluation of saffron (Crocus sativus L.) production in New Zealand, N.Z. J. Crop Hort. Sci. 25, 159-168.

Molina R.V., Garcìa-Luis A., Coll V., Ferrer C., Valero M. (2004a) Flower formation in the saffron Crocus (Crocus sativus L.), The role of temperature, Proceedings of the First International Symposium on Saffron Biology and Biotechnology, Acta Hort. 650, 39-47.

Molina R.V., Valero M., Navarro Y., Garcìa-Luis A., Guardiola J.R. (2004b) The effect of time of corm lifting and duration of incubation at inductive temperature on flowering in the saffron plant (Crocus sativus L.), Sci. Hort. 103, 79-91.

Mollafilabi A. (2004) Experimental findings of production and echo physiological aspects of saffron (Crocus sativus L.), Acta Hort. 650, $195-200$.

Mosaferi H. (2001) Effect of different regimens of irrigation on saffron yield, M.S. thesis of irrigation and drainage, Ferdowsi University of Mashhad, Iran.

Narasimhan S., Chand N., Rajalakshmi D. (1992) Saffron: quality evaluation by sensory profile and gas chromatography, J. Food Qual. 15, 303-314.

Negbi M. (1990) Physiological research on the Saffron Crocus (Crocus sativus), in: Tammaro F., Marra L. (Eds.), Lo zafferano, Proceedings of the international conference on saffron (Crocus sativus L.), L'Aquila (Italy), 27-29 October 1989.

Negbi M., Dagan B., Dror A., Basker D. (1989) Growth, flowering, vegetative reproduction and dormancy in the saffron crocus (Crocus sativus L.), Israel J. Bot. 38, 95-113.

Negbi M. (1999) Saffron cultivation: past, present and future prospects, in: Negbi M. (Ed.), Saffron: Crocus sativus L., Harwood Academic Publishers, Australia, pp. 1-18.

Ochiai T., Ohno S., Soeda S., Tanaka H., Shoyama Y., Shimeno H. (2004) Crocin prevents the death of rat pheochromyctoma (PC-12) cells by its antioxidant effects stronger than those of $\alpha$-tocopherol, Neurosci. Lett. 62, 61-64.

Papandreou M.A., Kanakis C.D., Polissiou M.G., Efthimiopoulos S., Cordopatis P., Margarity M., Lamari F.N. (2006) Inhibitory activity on amyloid- $\beta$-aggregation and antioxidant properties of Crocus sativus stigmas extract and its crocin constituents, J. Agr. Food Chem. 54, 8162-8168.

Pfander H., Schurteberger H. (1982) Biosynthesis of $\mathrm{C}_{20}$-carotenoids in Crocus sativus, Phytochemistry 21, 1039-1042.
Piccioli G. (1932) La coltura dello zafferano ne L’Aquila degli Abruzzi, Cellamare, L'Aquila (Italy).

Pignatti S. (1982) Flora d'Italia. I-III, Edagricole.

Plessner O., Negbi M., Ziv M., Basker D. (1989) Effect of temperature on the flowering of the saffron crocus (Crocus sativus L.): induction of hysteranthy, Israel J. Bot. 38, 1-7.

Raina B.L., Agarwal S.G., Bhatia A.K., Gaur G.S. (1996) Changes in pigments and volatiles of saffron (Crocus sativus L.) during processing and storage, J. Sci. Food Agr. 71, 27-32.

Roedel W., Petrzika M. (1991) Analysis of the volatile components of saffron, J. High Res. Chromatogr. 14, 771-774.

Rychener M., Bigler P., Pfander H. (1984) Isolierung und strukturaufklärung von neapolitanose $(O-\beta$-D-glucopyranosyl- $(1 \rightarrow 2)-O$-[ $\beta$-Dglucopyranosyl-( $1 \rightarrow 6)]$-(D-glucose), einen neuen trisaccharid aus den stempein von gartenkrokussen (Crocus neapolitanus var.), Helv. Chim. Acta 67, 386-391.

Rubio Moraga A., Fernández Nohales P., Fernández Pérez J., GómezGómez L. (2004) Glucosylation of the saffron apocarotenoid crocetin by a glucosyltransferase isolated from Crocus sativus stigmas, Planta 219, 955-966.

Sadeghi B. (1980) Effect of chemical fertilizer on saffron production, Annual Report, Korasan Agriculture Research centre.

Saito N., Mitsui S., Hayashi K. (1960) Anthocyanins. XXXIII. Delphin, the anthocyanin of medical saffron and its identity with hyacin by paper chromatography of partial hydrolyzates, Proc. Jpn Acad. 36, 340-345.

Sampathu S.R., Shivashankar S., Lewis Y.S. (1984) Saffron (Crocus sativus L.): Cultivation, processing, chemistry and standardization, Crit. Rev. Food Sci. Nutr. 20, 123-157.

Skrubis B. (1990) The cultivation in Greece of Crocus sativus L., in: Tammaro F., Marra L. (Eds.), Proceedings of the international conference on saffron (Crocus sativus L.), L'Aquila, pp. 171-182.

Soeda S., Ochiai T., Tanaka H., Shoyama Y., Shimeno H. (2005) Prevention of ischemic neuron death by a saffron's carotenoid pigment crocin and its mechanism of action, Focus Neurochem. Res. $139-156$

Straubinger M., Jezussek M., Waibel R., Winterhalter P. (1997) Novel glycosidic constituents from saffron, J. Agr. Food Chem. 45, 16781681.

Straubinger M., Bau B., Eckstein S., Fink M., Winterhalter P. (1998) Identification of novel glycosidic aroma precursors in saffron (Crocus sativus L.), J. Agr. Food Chem. 46, 328-3243.

Tammaro F. (1990) Crocus sativus L. - cv. Piano di Navelli (L'Aquila saffron): environment, cultivation, morphometric characteristics, active principles, uses, in: Tammaro F., Marra L. (Eds.), Proceedings of the international conference on saffron (Crocus sativus L.), L'Aquila, pp. 47-57.

Tammaro F. (1999) Saffron (Crocus sativus L.) in Italy, in: Negbi M. (Ed.), Saffron: Crocus sativus L., Harwood Academic Publishers, Australia, pp. 53-62.

Tammaro F., Di Francesco L. (1978) Lo zafferano dell'Aquila, Ist. Tecn. Prop. Agraria, Ministero Agricoltura e Foreste, Roma.

Tarantilis P.A., Polissiou M.G. (1997) Isolation and Identification of the Aroma Components from Saffron (Crocus sativus), J. Agr. Food Chem. 45, 459-462.

Tarantilis P.A., Polissiou M.G. (2004) Chemical analysis and antitumor activity of natural and semi-natural carotenoids of saffron., Acta Hort., 650, 447-461 (Proceedings of the 1st International Symposium on Saffron Biology and Biotechnology 2003).

Thiercelin J.-M. (2004) Room Table: Industrial Perspectives for saffron, Acta Hort. 650, 399-404. 
Trigoso C.I., Stockert J.C. (1995) Fluorescence of the natural dye saffron: selective reaction with eosinophil leucocyte granules, Histochem. Cell Biol. 104, 75-77.

Vavilov N.I. (1951) The origin, variation, immunity and breeding of cultivated plants, The Cronica Botanica, Co., Waltham, Mass.

Vickackaite V., Romani A., Pannacci D., Favaro G. (2004) Photochemical and thermal degradation of a naturally occurring dye used in artistic painting. A chromatographic, spectrophotometric and fluorimetric study on saffron, Int. J. Photoener. 6, 175-183.

Winterhalter P., Straubinger M. (2000) Saffron: Renewed interest in an ancient spice, Food Rev. Int. 16, 39-59.

Wu Z., Robinson D.S., Hughes R.K., Casey R., Hardy D., West S.I. (1999) Co-oxidation of $\beta$-carotene catalyzed by soybean and recombinant pea lipoxygenases, J. Agr. Food Chem. 47, 4899-4906.

Zaffar G., Wani S.A., Anjum T., Zeerak N.A. (2004) Colchine induced variability in saffron, Acta Hort. 650, 277-280.

Zalacain A., Ordoudi S.A., Blazquez I., Diaz-Plaza E.M., Carmona M., Tsimidou M.Z., Alonso G.L. (2005a) Screening method for the detection of artificial colours in saffron using derivative UV-Vis spectrometry after precipitation of crocetin, Food Addit. Contam. 22, 607-615.
Zalacain A., Ordoudi S.A., Diaz-Plaza E.M., Carmona M., Blazquez I., Tsimidou M.Z., Alonso G.L. (2005b) Near-infrared spectroscopy in saffron quality control: determination of chemical composition and geographical origin, J. Agr. Food Chem. 53, 9337-9341.

Zanzucchi C. (1987) Research carried out by the Consorzio Comunale Parmense on Saffron (Crocus sativus L.), Proceedings of the conference on the "coltivazione delle piante officinali", Trento 9-10 ottobre 1986, pp. 347-395.

Zougagh M., Rios A., Valcarcel M. (2005a) An automated screening method for the fast, simple discrimination between natural and artificial colorants in commercial saffron products, Anal. Chim. Acta $535,133-138$.

Zougagh M., Simonet B.M., Rios A., Valcarcel M. (2005b) Use of nonaqueous capillary electrophoresis for the quality control of commercial saffron samples, J. Chromatogr. A 1085, 293-298.

Zubor A.A., Suranyi G., Gyori Z., Borbely G., Prokisch J. (2004) Molecular biological approach of the Systematics of Crocus sativus L. and its allies, in: Abdullaev F. (Ed.), Proceedings of the First International Symposium on Saffron Biology and Biotechnology, pp. 85-93. 